\title{
Global status of DDT and its alternatives for use in vector control to prevent disease
}

\author{
Estado global do DDT e suas alternativas \\ para utilização no controle de vetores para prevenção de doenças
}

Henk van den Berg ${ }^{1}$

This article was originally published by Environ Health Perspect 117:1656 1663 (2009). doi:10.1289 ehp.0900785 available via http://dx.doi.org/ [Online 29 May 2009] and is part of the scientific collaboration between Cien Saude Colet and EHP.

${ }^{1}$ Laboratory of Entomology, Wageningen University. Timmerhout 13, 6846EC Arnhem, the Netherlands. henk.vandenberg@wur.nl

\begin{abstract}
In this article I reviewed the status of dichlorodiphenyltrichloroethane (DDT), used for disease vector control, and its benefits and risks in relation to the available alternatives. Contemporary data on DDT use were obtained from questionnaires and reports as well as a Scopus search to retrieve published articles. Nearly 14 countries use DDT for disease control, and several others are reintroducing DDT. Concerns about the continued use of DDT are fueled by recent reports of high levels of human exposure associated with indoor spraying amid accumulating evidence on chronic health effects. There are signs that more malaria vectors are becoming resistant to the toxic action of DDT. Effective chemical methods are available as immediate alternatives to DDT, but the development of resistance is undermining the efficacy of insecticidal tools. Nonchemical methods are potentially important, but their effectiveness at program level needs urgent study. To reduce reliance on DDT, support is needed for integrated and multipartner strategies of vector control. Integrated vector management provides a framework for developing and implementing effective technologies and strategies as sustainable alternatives to reliance on DDT.
\end{abstract}

Key words DDT, Indoor residual spraying, Integrated vector management, Malaria, Persistent organic pollutants, Vector control
Resumo Neste artigo, revisei o estado do diclorodifenil-tricloroetano (DDT) utilizado no controle de doenças causadas por vetores, e seus benefícios e riscos em relação às alternativas disponíveis. Dados atuais sobre o uso de DDT foram obtidos através de questionários e relatórios, assim como uma busca Scopus para resgatar artigos publicados. Quase 14 países utilizam DDT para controle de doenças, e diversos outros o estão reintroduzindo. A preocupação sobre o uso contínuo de DDT é abastecida por relatórios recentes dos altos níveis de exposição humana associada com a pulverização em recintos fechados, acumulando evidências sobre efeitos crônicos a saúde. Existem sinais de que mais vetores da malária estão se tornando resistentes à ação tóxica do DDT. Métodos quimicos efetivos estão disponiveis como alternativas imediatas ao DDT, mas o desenvolvimento da resistência está diminuindo a eficácia das ferramentas de insetização. Métodos não químicos são potencialmente importantes, mas sua efetividade no programa necessita de estudos urgentes. O controle integrado de vetores fornece uma estrutura para o desenvolvimento e a implementação de tecnologias e estratégias efetivas como alternativas sustentáveis à dependência ao DDT. Palavras-chave DDT, Resíduo de pulverização em recintos fechados, Controle integrado de vetores, Malária, Poluentes orgânicos persistentes, Controle de vetores 


\section{Introduction}

The Stockholm Convention seeks the elimination of 12 chemicals or classes of chemicals, one of which is dichlorodiphenyltrichloroethane $(\mathrm{DDT})^{1}$. DDT is used in indoor spraying for control of vectors of malaria and visceral leishmaniasis. In negotiations that led to the treaty, there was concern that a sudden ban on DDT use could adversely affect the malaria burden. Thus, DDT was permitted to be produced and used for the purpose of controlling disease vectors in accordance with recommendations and guidelines of the World Health Organization (WHO) and when locally safe, effective, and affordable alternatives are not available ${ }^{2}$. Ironically, DDT use in Africa has increased since the Stockholm Convention came into effect ${ }^{3}$.

Malaria is a complex parasitic disease confined mostly to tropical areas and trans-mitted by mosquitoes of the genus Anopheles. There are an estimated 250 million clinical cases of malaria, causing nearly a million deaths, mostly of children $<5$ years of age and mostly in sub-Saharan Africa ${ }^{4}$. Malaria-endemic countries are faced with a high cost of prevention and treatment of the disease.

Vector control is an essential component of malaria control programs. The WHO has reaffirmed the importance of vector control through indoor residual spraying (IRS) as one of the primary interventions for reducing or interrupting malaria transmission in countries in both stable and unstable transmission zones. Twelve insecticides have been recommended for IRS, including DDT. The course of action promoted by the WHO has been to retain DDT as part of the arsenal of insecti-cides available for IRS globally, to be able to manage insecticide resistance until suitable alternatives are available ${ }^{2}$. The use of DDT for IRS is recommended only where the intervention is appropriate and effective in the local epidemiologic situation. Nonetheless, DDT has not been subjected to the WHO's Pesticide Evaluation Scheme for many years.

In this review, I present the current situation regarding the use of DDT for vector control, covering aspects of production, use, legislation, costeffectiveness, health effects, environmental effects, insecticide resistance, monitoring, and evaluation. I provide an out-line of alternative methods, strategies, and new developments; discuss cost-effectiveness, current implementation, barriers, and gaps in implementing the alternatives; and present possible solutions to reduce reliance on DDT.
This review is based largely on a document commissioned by the Stockholm Convention Secretariat, which served as background paper for a global stakeholders' meeting to review the establishment of a global partnership to develop alternatives to DDT, held 3-5 November 2008 in Geneva, Switzerland.

\section{Methods}

Contemporary information on the production and use of DDT was obtained from (a) formal questionnaires by the Stockholm Convention Secretariat, completed by national authorities; (b) documents published by the Stockholm Convention; (c) direct communications with national authorities; and (d) information available from project proposals submitted to the Global Environment Facility ${ }^{5}$. Information has been supplemented with data presented by country delegates at workshops in the context of the Stockholm Convention.

I obtained information on side effects, insecticide resistance, cost-effectiveness, and alternatives from literature searches. I used the search engine Scopus ${ }^{6}$ to retrieve studies related to DDT and malaria, with vector control as additional search term. Because of the breadth of the subject matter, only the most relevant studies were selected, and reviews were prioritized. Old literature was accessed electronically, or hard copies were obtained from libraries. Additional information on insecticide resistance was obtained from web-based reports from the African Network on Vector Resistance (ANVR) ${ }^{7}$. Information on human exposure and health effects was based on reviews published over the past 5 years and supplemented with recent studies on exposure due to indoor spraying.

\section{Status of DDT}

\section{Production, use, and management}

DDT is currently being produced in three countries: India, China, and the Democratic People's Republic of Korea (DPRK; North Korea) (Table 1). By far the largest amounts are produced in India for the purpose of disease vector control. In China, the average annual production during the period 2000-2004 was 4,500 metric tons of DDT, but $80-90 \%$ was used in the production of Dicofol, an acaricide, and around $4 \%$ 
was used as additive in antifouling paints. The remainder was meant for malaria control and was exported. Recent information from the $\mathrm{DPRK}^{8}$ indicates that 160 metric tons of DDT is produced per year, for use mainly in agriculture (which is not acceptable under the Stockholm Convention) and a small portion for use in public health. India and China both export DDT to countries in Africa, either as technical product or as a formulation, for the purpose of vector control. DDT is being formulated in Ethiopia and South Africa with ingredients imported from China. South Africa exports some of its formulated product to other countries in Africa.
An estimated 5,000 metric tons of DDT (active ingredient) was used for disease vector control in 2005 (Table 1). The primary use is for malaria control, but approximately 1,000 metric tons/ year (20\% of global consumption) is used for control of visceral leishmaniasis restricted to India. India is by far the largest consumer of DDT, but in 2007 use was down one-fourth from the 2005 level. Mozambique, Zambia, and Zimbabwe have recently reintroduced the use of DDT. With the possible exception of the Dominican Republic, there is no reported use of DDT for disease vector control from the Americas. Use in Ecuador, Mexico, and Venezuela was phased out in

Table 1. Annual global production and use of DDT (in $103 \mathrm{~kg}$ active ingredient) in 2003, 2005, and 2007.

\begin{tabular}{|c|c|c|c|c|c|}
\hline Country & 2003 & 2005 & 2007 & Comment & Source \\
\hline \multicolumn{6}{|c|}{ Produce DDT for vector control } \\
\hline China $^{\text {a }}$ & 450 & 490 & NA & For export & $\mathrm{Pd}$ \\
\hline India $^{b}$ & 4,100 & 4,250 & 4,495 & For malaria and leishmaniasis & Pd, Ws, Dc \\
\hline DPRK & NA & NA & 5 & $>155$ metric tons for use in agriculture & UNITAR \\
\hline Global production & $<4,550$ & $<4,740$ & $>4,500$ & & \\
\hline \multicolumn{6}{|c|}{ Use DDT for vector control } \\
\hline Cameroon & 0 & 0 & 0 & Plan to pilot in 2009 & WHO \\
\hline China & 0 & 0 & 0 & Discontinued use in 2003 & $\mathrm{SC}$ \\
\hline Eritrea & 13 & 15 & 15 & Epidemic-prone areas & Qu, WHO \\
\hline Ethiopia & 272 & 398 & 371 & Epidemic-prone areas & WHO, Ws \\
\hline Gambia & 0 & 0 & NA & Reintroduction in 2008 & $\mathrm{Dc}$ \\
\hline India & 4,444 & 4,253 & 3,413 & For malaria and leischmaniasis & WHO, Dc \\
\hline DPRK & NA & NA & 5 & $>155$ metric tons used in agriculture & UNITAR \\
\hline Madagascar & 45 & 0 & 0 & Plan to resume use in 2009 & $\mathrm{Qu}$ \\
\hline Malawi & 0 & 0 & 0 & Plan to pilot in 2009 & WHO \\
\hline Mauritius & 1 & 1 & $<1$ & To prevent malaria introduction & Qu \\
\hline Morocco & 1 & 1 & 0 & For occacional outbreaks & $\mathrm{Qu}$ \\
\hline Mozambique & 0 & 308 & NA & Reintroduction in 2005 & $\mathrm{WHO}$ \\
\hline Myanmar & 1 & 1 & NA & Phasing out & WS \\
\hline Namibia & 40 & 10 & 40 & Long-term use & WHO \\
\hline Papua New Guinea & NA & NA & 0 & No recent use reported & $\mathrm{SC}$ \\
\hline South Africa & 54 & 62 & 66 & Reintroduction in 2000 & Qu, WHO \\
\hline Sudan & 75 & NA & 0 & No recent use reported & $\mathrm{Qu}, \mathrm{WHO}$ \\
\hline Swaziland & NA & 8 & 8 & Long-term use & WHO \\
\hline Uganda & 0 & 0 & NA & High Court prohibited use, 2008 & $\mathrm{SC}, \mathrm{Dc}$ \\
\hline Zambia & 7 & 26 & 22 & Reintroduction in 2000 & Ws, Qu, WHO \\
\hline Zimbabwe & 0 & 108 & 12 & Reintroduction in 2004 & $\mathrm{WHO}$ \\
\hline Global use & $>4,953$ & $>5,210$ & $>3,950$ & & \\
\hline
\end{tabular}

Abbreviations: Dc: Direct communication with national authorities; NA, not available; Pd: project proposals submitted to the Global Environment Facility; Qu: questionnaire on DDT by the Secretariat of the Stockholm Convention completed by national autorities; SC: documents published by the Secretariat; Ws: workshop presentations by country delegates in the context of the Stockholm Convention. Further information was obtained from the WHO and UNITAR reports, as indicated. ${ }^{a}$ The figure for 2005 was extrapolated from the total production; in addition to production for vector control, DDT is produced for Dicofol manufacture $(\sim 3,800$ metric tons per year) and for antifoulant paints $(\sim 200$ metric tons per year). ${ }^{\mathrm{b}} \mathrm{DDT}$ is also produced for dicofol manufacture ( 280 metric tons per year). 
2000. China has reported that no DDT has been used for disease vector control since 2003, and future use is reserved only for malaria outbreaks.

IRS programs are currently expanding in Africa, the main driver being the U.S. President's Malaria Initiative 9 . Pilot programs on IRS have been initiated in some African countries, and several other countries are considering reintroducing the intervention. In some of these countries, a decision has not been made on whether to use DDT in their IRS program. Hence, the use of DDT may be increasing - especially in African countries - because new countries are initiating IRS programs, including the use of DDT, and countries that are using DDT are expanding their IRS programs to stable transmission areas.

There is a paucity of data on DDT supplies. The available information indicates that large amounts of DDT are stored in many countries, but most of the stock is outdated or of unknown quality. Moreover, the transfer of DDT stock between countries is not always documented or reported, and this poses a problem in tracking quantities of the chemical and establishing the quality of DDT being used. A major multistakeholder effort is needed for the cleanup of outdated DDT stock, for example, through the Africa Stockpiles Programme ${ }^{10}$.

Many countries that use DDT have inadequate legislation or lack capacity to implement or enforce regulations on pesticide management. Unpublished information suggests that DDT is being traded on local markets for use in agriculture and termite control ${ }^{11}$. Funding agencies aiding in the purchase of DDT should be obligated to provide financial assistance to ensure that regulations and monitoring capacity are in place to support proper management of DDT from the cradle to the grave, for example, by involving the environmental sector.

\section{Cost-effectiveness of DDT}

No published data exist on cost-effectiveness in terms of cost per disability-adjusted life-year averted by IRS using DDT. Statements of high cost-effectiveness of DDT have been based on the positive experience from the malaria eradication era $^{12}$ supplemented with more recent results on reductions in malaria morbidity and incidence associ-ated with the use of DDT ${ }^{13-15}$.

Both the effectiveness and costs of DDT are dependent on local settings and merit careful consideration in relation to alternative products or methods. DDT has been known as the only in- secticide that can be used as single application in areas where the transmission season is $>6$ months. However, information is lacking on the potential variability in residual action of insecticides, including DDT (e.g., due to sprayable surface, climatic conditions, social factors).

Direct costs of IRS are the procurement and transport of insecticide, training of staff, operations, awareness-raising of communities, safety measures, monitoring of efficacy and insecticide resistance, monitoring of adverse effects on health and the environment, and storage and disposal. In 1990, the insecticide costs per house per 6 months of control were substantially lower for DDT (US\$1.60) than for other insecticides (> US\$3.40), but in 1998 the cost range for DDT (US\$1.50-3.00) overlapped with that of alternative insecticides (> US\$2.20), pyrethroids in par-ticular ${ }^{16}$. This comparison will further change with the availability of new formulations of pyrethroids that have increased residual activity. Moreover, incorporating the cost of safety measures in the application of DDT will significantly change its comparative cost advantage.

Apart from the direct costs, it is essential that the unintended costs of DDT (or alternative insecticides) to human health and the environment are included in the cost assessment. In addition, contamination of food crops with DDT could negatively affect food export ${ }^{17}$. A comprehensive cost assessment of DDT versus its alternatives should include the potential costs of atmospheric transport and chronic health effects.

Proposed and ongoing projects by the WHO, United Nations Environment Programme, and United Nations Development Programme are expected to establish a more solid evidence base for the effectiveness of DDT in relation to its alternatives ${ }^{18}$. The results will be crucial in future decision making on vector management strategies for prevention of malaria.

\section{Health effects of DDT}

High levels of human exposure to DDT among those living in sprayed houses, most of whom are living under conditions of poverty and often with high levels of immune impairment, have been found in recent studies in South Africa and Mexico ${ }^{19-22}$, but contemporary peer-reviewed data from India, the largest consumer of DDT, are lacking. The simultaneous presence of, and possible interaction between, DDT, dichlorodiphenyldichloroethylene (DDE), and pyrethroids in human tissue is another area of con- 
cern $^{23,24}$. In North America, rather high levels of exposure have been recorded in biological samples collected near the time of peak use during the $1960 s^{25}$. Exposure of the fetus and young child occurs through the placenta and through lactation $^{23}$; exposure of children and adults occurs through direct contact with DDT in the environment, through indoor dust ${ }^{26}$, and through the food chain. DDT accumulates in fatty tissue and is slowly released. A monitoring system is needed for the assessment of trends in exposure to DDT, allowing for the attribution of effects to IRS locally; in this regard, human milk is considered an important media to be monitored ${ }^{27}$.

Studies on health effects of DDT have focused mostly on subjects in North America and Europe, who have generally been exposed to levels lower than those reported from areas with IRS. No global assessment has been made on the evidence of health risks of DDT in relation to IRS because data are scarce. As an indication, however, initial work suggests that nonoccupational exposure through IRS is associated with impaired semen quality in men ${ }^{19,21}$.

Health effects of DDT and DDE most commonly suggested by studies in North America and Europe are early pregnancy loss, fertility loss, leukemia, pancreatic cancer, neurodevelopmental deficits, diabetes, and breast cancer ${ }^{28-35}$. In many cases the results have not been consistent between studies, but nevertheless these accumulating reports bear much concern, particularly in relation to chronic effects. Breast cancer has been most rigorously studied; even though the majority of results showed no causative association with DDT exposure ${ }^{36}$, the latest evidence indicates an increased risk in women who were exposed at a young age ${ }^{37}$. In addition, experimental studies on animals have demonstrated neurotoxic, carcinogenic, immunotoxic, and reproductive effects attributable to DDT and $\mathrm{DDE}^{38}$.

The adverse health effects of DDT versus the health gains in terms of malaria prevention require more attention. For example, a gain in infant survival resulting from malaria control could be partly offset by an increase in preterm birth and decreased lactation, both of which are high risk factors for infant mortality in developing countries. The WHO is conducting a reevaluation of health risks of DDT, but progress has been slow.

\section{Environmental effects of DDT}

As a persistent molecule, DDT has low to very low rates of metabolism and disposition, depending on ambient temperatures. It is degraded slowly into its main metabolic products, DDE and dichlorodiphenyldichloroethane (DDD), which have similar physicochemical properties but differ in biological activity. DDT is emitted through volatilization and runoff. It is more volatile in warmer than in colder parts of the world, which through long-range atmospheric transport results in a net deposition and thus gradual accumulation at high latitudes and altitudes ${ }^{39}$.

Loss through runoff is low because DDT has a strong affinity for organic matter in soils and aquatic sediment but is virtually insoluble in water. Half-lives of DDT have been reported in the range of 3-7 months in tropi-cal soils ${ }^{40,41}$ and up to 15 years in temperate soils ${ }^{42}$. The half-life of each of its metabolic products is similar or longer. DDT readily binds with fatty tissue in any living organism, and because of its stability, bioconcentrates and biomagnifies with increasing trophic level in food chains ${ }^{43}$. The half-life of DDT in humans is $>4$ years; the half-life for DDE is probably longer ${ }^{24}$. Studies have shown that DDT is highly toxic to insects, shrimp, and fish ${ }^{44-46}$ and adversely affects the reproduction of wild birds through thinning of egg shells ${ }^{47}$.

DDT and its metabolic products present in the global environment have originated mostly from its previous large-scale use in agriculture and domestic hygiene. Because DDT is currently allowed only for indoor spraying for disease vector control, its use is much smaller than in the past. Nevertheless, DDT sprayed indoors may end up in the environment (e.g., when mud blocks of abandoned houses are dissolved in the rain). Data from Brazil, India, Mexico, and South Africa suggested that higher levels of DDT are found in water or soil samples in areas with DDT residual spraying than in areas without spray-ing ${ }^{22,48-51}$, but these results need further verification.

\section{Insecticide resistance}

As the number and size of programs that use DDT for indoor spraying increase, insecticide resistance is a matter of growing concern. Since the introduction of DDT for mosquito control in 1946, DDT resistance at various levels has been reported from $>50$ species of anopheline mosquitoes, including many vectors of malaria ${ }^{52}$. Unless due attention is paid to the role of insecticide resistance in the breakdown of the malaria eradication campaign of the 1960s, resistance may once again undermine malaria control ${ }^{53}$.

In the past, the use of DDT in agriculture was considered a major cause of DDT resistance in 
malaria vectors, as many vectors breed in agricultural environments ${ }^{54}$. At present, DDT resistance is thought to be triggered further by the use of synthetic pyrethroids ${ }^{55}$. This is due to a mechanism of cross-resistance between pyrethroids and DDT, the so-called sodium channel mutation affecting neuronal signal transmission, which is governed by the $k d r$ (knock-down resistance) gene ${ }^{56}$. Vectors with the $k d r$ gene are resistant to both groups of insecticides, and this has serious consequences for malaria vector control, because pyrethroids and DDT are the two main groups of chemicals used. The $k d r$ gene is being reported from an increasing number of countries; thus, even in countries without a history of DDT use, resistance to DDT is emerging in populations of malaria vectors ${ }^{57}$.

Contemporary data from sentinel sites in Africa indicate that the occurrence of resistance to DDT is widespread, especially in West and Central Africa ${ }^{7,58}$. The main African vector, Anopheles gambiae s.s., showed resistance to DDT in the majority of tests. Further, there is recent evidence of resistance in A. gambiae s.l. in Ethiopia ${ }^{7}$, and there are signs of DDT resistance in Anopheles arabiensis, another key vector, from Uganda, Cameroon, Sudan, Zimbabwe, and South Africa. In Asia, the resistance to DDT is particularly widespread in India. Multiple resistance to DDT and other insecticides in the major vector Anopheles culicifacies is present in many parts of the country ${ }^{59}$ and has reportedly caused a major loss in effectiveness of intervention ${ }^{60}$. Resistance has also been reported in Anopheles sinensis from China ${ }^{61}$ and in Anopheles epiroticus (formerly named Anopheles sundaicus) in Vietnam ${ }^{62}$.

Resistance does not necessarily result in failure to control disease. Standard testing of DDT resistance focuses on the insecticide's toxic action. However, the repellent and irritant properties of DDT also have the potential to reduce transmission of disease and relieve the selective pressure for toxic resistance ${ }^{63,64}$. This is an area requiring more research.

An important lesson learned from the experience with oncocerciasis (river blindness), another vector-borne disease, is that the development and spread of insecticide resistance is much slower when vector populations are under effective control ${ }^{65}$, suggesting that suppressing vector proliferation helps prevent or delay the development of resistance.

Effective monitoring and decision support systems can enable insecticide resistance to be detected at an early stage, which should lead to the implementation of changes in insec-ticide poli$\mathrm{cy}^{15}$. However, the choice of unrelated insecticides remains limited ${ }^{66}$. Even an intelligent insecticide resistance management strategy using rotations, mosaics, or mixtures may not prevent resistance development ${ }^{67,68}$. In a recent report from India, the Joint Monitoring Mission ${ }^{69}$ pointed out that the insecticide choice for IRS is rarely based on contemporary insecticide susceptibility testing.

\section{Alternatives to DDT}

A number of vector control methods are available as alternatives to DDT. Two of these, the use of alternative insecticides in IRS and the use of insecticide-treated bed nets (ITNs), are mainstreamed because of their proven impact on the malaria burden. Other available alternatives are receiving limited attention in contemporary malaria control efforts, but have an important role to play. Table 2 summarizes alternative methods. Alternatives to DDT should pose less risk to human health and the environment and be supported with monitoring data.

\section{Chemical methods}

IRS with insecticides is an effective method of malaria control. Its strength lies in its effect on shortening the life span of adult mosquitoes near their human targets, which has a critical impact on malaria transmission ${ }^{70}$. However, there is limited information on effectiveness and operational feasibility of IRS in African countries with highly endemic malaria, some of which recently reintroduced IRS or plan to do so. Twelve insecticides belonging to four chemical classes are recommended for IRS in vector control, which collectively address only three modes of toxic action $^{66}$. Pyrethroids are the most cost-effective alternatives to DDT in malaria control except where pyrethroid resistance occurs ${ }^{16}$.

There are two new developments with regard to IRS. First, some existing insecticides not currently available for public health; chlorfenapyr and indoxacarb, for example, showed potential in areas with pyrethroid resistance ${ }^{71,72}$. Second, new formulations of existing insecticides with prolonged residual activity are being developed as alternatives to $\mathrm{DDT}^{73}$. Two slow-release formulations of pyrethroids are already available on the market.

The main current alternative to IRS is the use of ITNs. The insecticide enhances the protective 
Table 2. Alternative methods for malaria vector control, indicating the targeted vector stage, the potential risk, and required resources and delivery mechanisms.

\begin{tabular}{|c|c|c|c|}
\hline Vector management method & Vector stage & Risk $^{\text {a }}$ & Resources/delivery \\
\hline \multicolumn{4}{|l|}{ Chemical methods } \\
\hline Insecticide-treated bed nets & Adult & Resistance, toxicity & $\begin{array}{l}\text { Free distribution, social marketing, } \\
\text { private sector }\end{array}$ \\
\hline Indoor residual spraying & Adult & Resistance, toxicity & Spray teams \\
\hline Chemical larviciding & Larva & Resistance, effect on ecosystems & Spray teams \\
\hline Repellents and attractants ${ }^{b}$ & Adult & Toxicity & Local, private sector \\
\hline \multicolumn{4}{|l|}{ Nonchemicals methods } \\
\hline Elimination of breeding sites & Larva & - & Local \\
\hline Habitat manipulation & Larva & - & Local, agriculture sector \\
\hline Irrigation management & Larva & - & Local, irrigation sector \\
\hline Design of irrigation structures & Larva & - & Irrigation sector \\
\hline House improvement & Adult & - & Local, development programs \\
\hline Predation & Larva & - & Local, programs, agriculture sector \\
\hline Microbial larvicides & Larva & Resistance & Programs, private sector \\
\hline Botanicals & Larva/Adult & Toxicity & Local \\
\hline Polystyrene beads & Larva & - & Local \\
\hline Fungi ${ }^{b}$ & Adult & - & Not applicable \\
\hline Genetic methods ${ }^{b}$ & Adult & To be studied & Not applicable \\
\hline
\end{tabular}

—, Negligible risk. ${ }^{\mathrm{a}}$ Theoretically, (behavioral) resistance could also develop against repellents, attractants, and house improvement. ${ }^{\mathrm{b}}$ (Partly) under development.

effect for the person under the net, but also has a beneficial effect on the community at large $\mathrm{e}^{74}$. ITNs have been shown convincingly to cause substantial reductions in all-cause child mortality, under both experimental ${ }^{75}$ and operational conditions $^{76,77}$. They are effective in highly endemic settings by reducing the risk of severe disease, particularly in infants and young children before they have acquired a certain level of natural immuni$\mathrm{ty}^{78}$. Two categories of ITNs are available: conventionally treated nets and long-lasting ITNs. The former needs regular retreatment, a followup action that has proven difficult to achieve at field level. The latter is a relatively new technology that retains the efficacy for at least 3 years. Pyrethroids are the only chemical group recommended for use in ITNs.

There have been several new developments in ITN technology. Research on treatment with nonpyrethroids has been conducted to cope with the problem of resistance, but safety issues are a concern. At least one insecticide with novel chemistry is being developed for ITNs ${ }^{73}$. It is critical that this unique product, once it enters the market, is reserved solely for public health purposes, thus reducing the risk of insecticide resistance in the future. New ITN products are not expected to come to market in the short term.

The relative cost-effectiveness of IRS and ITNs has been studied on several occasions. Both have been considered attractive interventions in terms of cost per disability-adjusted life-years averted ${ }^{79}$, but their relative effectiveness depends on vector behavior and human sleeping habits in a given setting. ITNs are generally more cost-effective in highly endemic settings ${ }^{80}$, whereas IRS operations can respond faster to epidemic situations ${ }^{81}$.

The use of chemical insecticides as larvicides to control mosquito breeding can play an important role in malaria control where this is appropriate and feasible, particularly in urban settings, but the broad-spectrum effects of most chemicals are a concern to the integrity of aquatic ecosystems. Moreover, chemical repellents could have a useful supplementary role in vector con$\mathrm{trol}^{82}$. Innovative work is in progress on the attractiveness of human odors to malaria vectors, with potential applications as mosquito attractants and repellents for use in trapping and personal protection ${ }^{83}$. 


\section{Nonchemical methods}

"Environmental management for vector control" is the collective term for manipulating or modifying environmental factors or their interaction with humans to reduce vector breeding and vector-human contact. Before the advent of synthetic insecticides, vector control depended primarily on environmental management; a metaanalysis of data mostly from that period indicated that it substantially reduced malaria risk ${ }^{84}$. Eliminating vector-breeding habitats and managing water bodies has the potential to suppress vector populations, particularly in human-made habitats or urban settings ${ }^{85}$. In irrigated agriculture, vector breeding can be controlled, for example, through land leveling and intermittent irrigation ${ }^{86}$. New irrigation systems or dams cause drastic changes in vector-human contact, and planning to avoid health risks is essential at the design stage.

Improvement of housing, for example, through plastering of walls or closing of eaves, contributes significantly to transmission control $^{87}$. Moreover, screening to keep mosquitoes out at night is a protective option for houses with solid walls ${ }^{88}$. However, information on the cost and feasibility of housing improvement in various settings is largely missing.

The role of aquatic predators as control agents of malaria vectors is potentially enhanced through conservation or through the introduction of agents from outside. Larvivorous fish have frequently been reared and released for controlling vector breeding in small water tanks and wells, but successes have generally been limited to more or less permanent water bodies ${ }^{85}$.

The bacteria Bacillus thuringiensis israelensis and Bacillus sphaericus are used in formulations as microbial larvicides. They produce toxins that are specific to mosquitoes and that have a low risk of resistance development ${ }^{89}$. Recent field trials and pilot projects have shown good potential of both bacteria to manage mosquito breeding and to reduce biting rates in certain settings ${ }^{90}$. Insect pathogenic fungi have shown promising results for controlling adult Anopheles mosquitoes when sprayed on indoor surfaces and have potential to substantially reduce malaria transmission ${ }^{91}$. Other alternative vector control methods include the use of locally available plants or plant materials as mosquito repellents or as larvicides $^{92,93}$, and the use of expanded polystyrene beads in specific breeding sites ${ }^{94}$. Novel methods under development are genetically engineered mosquitoes and the sterile insect technique ${ }^{95}$.
Data on the cost-effectiveness of nonchemical methods are scarce. In a retrospective analysis of data from Zambia, Utzinger et al. ${ }^{96}$ indicated that environmental management was as costeffective as ITNs. Moreover, environmental management can benefit from local resources, reducing the need for external funds.

\section{Current implementation of DDT alternatives}

The past decade has seen a steady increase in commitment to malaria control by the international community ${ }^{97}$. This has caused a boost in financial and human resources available for implementation of vector control interventions, due to the support of the Global Fund, the World Bank, the U.S. President's Malaria Initiative, and many nongovernmental organizations.

China, the Solomon Islands, and Vietnam have largely replaced their IRS programs with ITNs during the past decades ${ }^{98}$. Conversely, the use of IRS is on the increase in Africa, where it has been more difficult to come to grips with malaria because of aspects of vector biology and disease epidemiology. In South Asia, indoor spraying using DDT and alternative insecticides continues on a large scale, but the quality of the intervention is a critical issue ${ }^{69}$.

National campaigns of free or highly subsidized ITNs, often in combination with other malaria control interventions, have reportedly approached coverage levels of $\geq 50 \%$ among households in a number of African countries, resulting in dramatic reductions in the malaria incidence ${ }^{4,99-101}$.

Nonchemical methods, such as environmental management and biological control have been promoted or tested in pilot projects. However, contemporary cases of sustained implementation are not common. Case examples include the use of intermittent irrigation in China ${ }^{102}$, integrated and participatory strategies in Mexico ${ }^{103}$ and In$\mathrm{dia}^{104}$, river flow management in Sri Lanka ${ }^{105}$, and the use of farmer field schools on vector management in agriculture in Sri Lanka ${ }^{106}$.

\section{Barriers and gaps}

Several barriers exist in the implementation of alternatives to DDT. Vector resistance to insecticides is a direct threat to the sustainability of ITNs and IRS. Resistance to pyrethroids has been reported in malaria vectors from West, East, and southern Africa ${ }^{7,58}$. Particularly, $k d r$-type cross- 
resistance between pyrethroids and DDT severely limits the choice of insecticide. South Africa was forced to reintroduce DDT after failure of pyrethroids, due to one of the locally extinct vectors returning and having acquired pyrethroid resistance (not $k d r$-type) elsewhere ${ }^{107}$.

There is growing concern about sustained effectiveness of ITNs because the intervention currently depends solely on pyrethroid insecticides ${ }^{108}$. Multivillage studies in an area with highly resistant A. gambiae in Côte d'Ivoire indicated that ITNs retained most of their effect ${ }^{109,110}$. The explanation for this finding was that resistant mosquitoes were less irritated, which resulted in a higher uptake of insecticide. More worrisome are the results of a semi-field study from an area with highly resistant vectors in Benin ${ }^{111}$, which showed a major loss in efficacy of ITNs locally. Without the insecticidal action, bed nets provide a much lower level of personal protection ${ }^{75}$.

Resistance is caused by the use of insecticides in agriculture ${ }^{55}$ and in public health. There is evidence of increased frequencies of resistance genes attributable to IRS or ITN programs $s^{112,113}$. Moreover, there are records of a change in vector behavior from indoor resting to out-door resting in response to indoor spraying, as well as a change in daily pattern of biting and host choice in response to ITN interventions ${ }^{114-117}$. A system of sentinel sites to monitor vector density, quantify insecticide resistance, and guide informed decision making on insecticide choice still needs to be established in most disease-endemic countries ${ }^{118}$.

Another barrier is operational capacity. The effective coverage of programs depends critically on the access and targeting of populations and vulnerable groups most at risk of malaria, the degree of compliance of the provider, and adherence by the consumer. In most countries with endemic malaria, health systems lack capacity to plan and implement programs effectively. Reforms in the health sector have led to the decentralization of planning and budgeting. Consequently, the responsibility for service provision has shifted from national to subnational or district-level health departments, requiring new skills for malaria control at each level. An analysis of case studies from four countries suggested that decentralization can potentially benefit malaria control $^{119}$. In general, however, there is a lack of guidance on how malaria control might be implemented in a decentralized environment ${ }^{120}$.

Traditionally, IRS has been managed as vertical programs, which is still the case in various countries. In some countries the transition pro- cess after health reforms has caused an erosion of the specialist skills needed for IRS ${ }^{121}$. It will be a challenge for many countries to conduct and sustain effective IRS programs ${ }^{122}$. The delivery of ITNs has used a variety of models, including vertical programs, integrated health sector programs, and involvement of the private sector and nongovernmental organizations ${ }^{123}$. As the global thrust is to promote coverage with ITNs and IRS, vector control capacity is needed at the appropriate levels.

Interventions involving environmental management and other larval control methods depend on the participation of other sectors and communities. Even though decisions affecting the risk of vector-borne disease are taken in other public sectors, there is insufficient awareness of the effects. Moreover, the health sector lacks capacity to facilitate community participation and education. A possible solution is the integration of health activities with community programs that generate income (e.g., from agriculture). Rich experience with participatory approaches exists within the agriculture sector ${ }^{124}$; the health sector potentially can benefit from these resources. One relevant model is the Farmer Field School on Integrated Pest Management, developed and promoted by the Food and Agriculture Organization of the United Nations ${ }^{125}$.

\section{Integration of methods}

An integrated approach to vector control has frequently been advocated ${ }^{121,126,127}$. The need for a reduced reliance on insecticides for vector-borne disease control, as pointed out in World Health Assembly Resolution $50.13^{128}$, has been stressed further by the Intergovernmental Forum on Chemical Safety, Forum VI ${ }^{129}$.

Various studies have demonstrated that integration of vector control methods resulted in significant reductions in transmission and morbidity rates of malaria ${ }^{96,103,130-133}$. Moreover, modeling studies predicted that combinations of interventions can be much more effective in reducing malaria transmission than individual interventions and that the effect of IRS and ITNs is amplified by environmental management, even in areas of intense transmission ${ }^{134,135}$.

Besides its direct effect on transmission intensity, the integration of methods may also contribute to resistance management. For example, larval control is expected to prevent or delay the onset of vector resistance to insecticides ${ }^{85}$, whereas measures that reduce human contact with vec- 
tors, through their proximity, housing conditions, or presence of repellents, for example, will reduce the selection pressure.

\section{Integrated vector management}

Modeled on the positive experience from integrated pest management in agriculture, integrated vector management (IVM) has been defined by the $\mathrm{WHO}^{136}$ as "a rational decision-making process for the optimal use of resources for vector control." The aim of IVM is to improve cost-effectiveness, ecologic soundness, and sustainability of disease vector control ${ }^{137,138}$. In contrast to conventional vector control programs with a top-down decision-making structure, IVM emphasizes decision making at the lowest possible level in accordance with local data collection and situational analysis, and requires collaboration within the health sector and with other sectors, as well as community participation. Hence, decentralization in the health sector can potentially work in favor of IVM by facilitating tailored action at the local level ${ }^{139}$.

The Global Malaria Action Plan advocates the scaling-up of ITNs and IRS for an immediate impact on the malaria burden of populations at risk ${ }^{140}$. However, to address sustainability issues, interventions must be implemented in accordance with an IVM approach by being evidence-based and by integrating available resources and supplementary methods in an effective and ecologically sound manner. To enable the graduation from a conventional vector control program to IVM, the evidence base and human capacity needs strengthening at all relevant levels of administration. Recently, targets have been set for the elimi-nation of malar$\mathrm{ia}^{141}$. An IVM approach is important to sustain achievements and reduce transmission to critical low levels needed to eliminate malaria ${ }^{142}$.

\section{Conclusions}

The reported global use of DDT for disease vector control is 4-5,000 metric tons per year, with India by far the largest consumer and several countries reintroducing DDT. The insecticide is known for its long residual effect and low operational cost. However, the effectiveness of DDT depends on local settings and merits closer con- sideration vis à vis chemical and nonchemical alternatives. Legislation and capacity to enforce regulations and management practice is inadequate in most countries.

Recent evidence indicates that indoor spraying causes high levels of human exposure to $\mathrm{DDT}^{17}$. This could adversely affect human health, because the evidence base on some of the more serious and chronic health effects of DDT is growing. Moreover, the occurrence of resistance to the toxic action of DDT is common in malaria vectors and appears to be spreading. A comprehensive cost assessment of DDT versus its alternatives is needed and should include the monitoring of side effects and unintended costs to human health, the environment, and international trade.

Effective chemical alternatives to DDT for vector control are available, but the choice of insecticides is limited. Insecticides with novel chemistry will not come to market in the short term. Alternative insecticides should pose less risk to human health and the environment. The coverage of populations with ITNs and IRS has increased in recent years, particularly in Africa. However, insecticide resistance is reducing the efficacy of these methods in certain areas. To be prepared for future emergencies, the continued effectiveness of insecticides needs to be safeguarded.

A number of nonchemical methods have proven their value in malaria control in certain settings, but more work is needed on the incremental impact of methods such as environmental management or the use of microbial larvicides when used in conjunction with IRS and ITNs. Several new technologies are under development but require increased investment. To continue this development, we must foster new researchers in the field of vector control.

To reduce reliance on DDT, support is needed for integrated and multipartner strategies of vector control. IVM provides a framework for improving cost-effectiveness, ecologic soundness, and sustainability of vector control through integration with other arms of public health and other sectors. Now that malaria transmission is decreasing in a number of African countries, there is a greater prospective role for environmental management and other nonchemical methods within IVM strategies. This will increase the sustainability of control efforts and assist in achieving malaria elimination objectives. 


\section{Acknowledgements}

I thank W. Takken and the anonymous experts for their valuable input. The Secretariat of the Stockholm Convention commissioned the study and conducted a scientific peer review of the document that served as the basis for this paper. The Secretariat granted permission for publication. The views expressed in this paper do not necessarily represent the official position of the Secretariat of the Stockholm Convention. The author has acted as advisor and expert committee member in relation to DDT and vector control for several United Nations organizations. This has involved compensation for travel and consultancies.

\section{References}

1. United Nations Environment Programme (UNEP). Stockholm convention on persistent organic pol-lutants (POPs) - UNEP/Chemicals/2002/9. Geneva: United Nations Environment Programme; 2002.

2. World Health Organization (WHO). The use of DDT in malaria vector control: WHO position statement. Geneva: World Health Organization; 2007.

3. Manga L, personal communication.

4. World Health Organization (WHO). World Malaria Report 2008. Geneva: World Health Organization; 2008.

5. Global Environment Facility. The GEF Project Database; 2009. [accessed 22 September 2009]. Available: http://gefonline.org/home.cfm

6. Scopus. Everything you need to know about Scopus; 2008. [accessed 22 September 2009]. Available: http://info.scopus.com/

7. Vector Biology and Control. World Health Organization Regional Office for Africa. Vector Biology and Control Reports; 2008. [accessed 23 September 2009]. Available: http://www.afro.who.int/vbc/reports/

8. United Nations Institute for Training and Research (UNITAR), unpub-lished data.

9. President's Malaria Initiative. PMI homepage; 2009. [accessed 22 September 2009]. Available: http:// www.fightingmalaria.gov/

10. Curtis C, Olsen CP. The Africa Stockpiles Programme: cleaning up obsolete pesticides - contributing to a healthier future. Ind Environ 2004; 27(23):37-38.

11. United Nations Environment Programme (UNEP). Persistent organic pollutants: workshop proceedings. Geneva: United Nations Environment Programme; 2008. [accessed 22 September 2009]. Available: http:/ /www.chem.unep.ch/Pops/POPs_Inc/proceedings/ coverpgs/procovers.htm

12. Mabaso MLH, Sharp B, Lengeler C. Historical review of malarial control in southern African with emphasis on the use of indoor residual house-spraying. Trop Med Int Health 2004; 9:846-856.

13. Curtis CF. Restoration of malaria control in the Madagascar highlands by DDT spraying. Am J Trop Med Hyg 2002; 66:1.

14. Gunasekaran K, Sahu SS, Jambulingam P, Das PK. DDT indoor residual spray, still an effective tool to control Anopheles fluviatilis-transmitted Plasmodium falciparum malaria in India. Trop Med Int Health 2005; 10:160-168.

15. Sharp BL, Kleinschmidt I, Streat E, Maharaj R, Barnes KI, Durrheim DN, Ridl FC, Morris N, Seocharan I, Kunene S, La Grange JJ, Mthembu JD, Maartens F, Martin CL, Barreto A. Seven years of regional malaria control collaboration: Mozambique, South Africa, and Swaziland. Am J Trop Med Hyg 2007; 76:42-47.

16. Walker K. Cost-comparison of DDT and alternative insecticides for malaria control. Med Vet Entomol 2000; 14:345-354.

17. Anonymous. DDT for malaria control: the issue of trade (editorial). Lancet 2007; 369:248. 
18. World Health Organization (WHO). Update for $\mathrm{COP} 3$ on WHO activities relevant to country implementation of the Stockholm Convention on Persistent Organic Pollutants. Geneva: World Health Organization; 2007. [accessed 22 September 2009]. Available: http://www.who.int/ipcs/capacity_building/ COP3\%20update.pdf

19. Aneck-Hahn NH, Schulenburg GW, Bornman MS, Farias P, De Jager C. Impaired semen quality associated with environmental DDT exposure in young men living in a malaria area in the Limpopo Province, South Africa. J Androl 2007; 28:423-434.

20. Bouwman H, Cooppan RM, Becker PJ, Ngxongo S. Malaria control and levels of DDT in serum of two populations in Kwazulu. J Toxicol Environ Health 1991; 33:141-155.

21. De Jager C, Farias P, Barraza-Villarreal A, Avila $\mathrm{MH}$, Ayotte P, Dewailly E, Dombrowski C, Rousseau F, Sanchez VD, Bailey JL. Reduced seminal parameters associ-ated with environmental DDT exposure and $p, p^{\prime}$-DDE concentrations in men in Chiapas, Mexico: a cross-sectional study. J Androl 2006; 27:16-27.

22. Yanez L, Ortiz-Perez D, Batres LE, Borja-Aburto VH, Diaz-Barriga F. Levels of dichlorodiphenyltrichloroethane and deltamethrin in humans and environmental samples in malarious areas of Mexico. Environ Res 2002; 88:174-181.

23. Bouwman H, Sereda B, Meinhardt HM. Simultaneous presence of DDT and pyrethroid residues in human breast milk from a malaria endemic area in South Africa. Environ Pollut 2006; 144:902-917.

24. Longnecker MP. Invited commentary: why DDT matters now. Am J Epidemiol 2005; 162:726-728.

25. Eskenazi B, Chevrier J, Rosas LG, Anderson HA, Bornman MS, Bouwman H, Chen A, Cohn BA, de Jager C, Henshel DS, Leipzig F, Leipzig JS, Lorenz EC, Snedeker SM, Stapleton D. The Pine River statement: human health consequences of DDT use. Environ Health Perspect 2009; 117:1359-1367; doi:10.1289/ehp.11748 (online 4 May 2009).

26. Herrera-Portugal C, Ochoa H, Franco-Sanchez G, Yanez L, Diaz-Barriga F. Environmental pathways of exposure to DDT for children living in a malarious area of Chiapas, Mexico. Environ Res 2005; 99:158-163.

27. Malisch R, van Leeuwen FXR. Results of the WHOcoordinated exposure study on the levels of PCBs, PCDDs and PCDFs in human milk. Organohalogen Compounds 2003; 64:140-143.

28. Beard J. DDT and human health. Sci Total Environ 2006; 355:78-89.

29. Chen A, Rogan WJ. Nonmalarial infant deaths and DDT use for malaria control. Emerg Infect Dis 2003; 9:960-964.

30. Cox S, Niskar AS, Narayan KM, Marcus M. Prevalence of self-reported diabetes and exposure to organochlorine pesticides among Mexican Americans: Hispanic Health and Nutrition Examination Survey, 1982-1984. Environ Health Perspect 2007; 115:17471752.

31. Eriksson P, Talts U. Neonatal exposure to neurotoxic pesticides increases adult susceptibility: a review of current findings. Neurotoxicology 2000; 21:37-47.
32. Garabrant DH, Held J, Langholz B, Peters JM, Mack TM. DDT and related compounds and risk of pancreatic cancer. J Natl Cancer Inst 1992; 84:764-771.

33. Ribas-Fito N, Torrent M, Carrizo D, Munoz-Ortiz L, Julvez J, Grimalt JO, Sunyer J. In utero exposure to background concentrations of DDT and cognitive functioning among preschoolers. Am J Epidemiol 2006; 164:955-962.

34. Snedeker SM. Pesticides and breast cancer risk: a review of DDT, DDE, and dieldrin. Environ Health Perspect 2001; 109:35-47.

35. Venners S, Korrick S, Xu X, Chen C, Guang W, Huang A, Altshul L, Perry M, Fu L, Wang Xet. Preconception serum DDT and pregnancy loss: a prospective study using a biomarker of pregnancy. $A m$ J Epidemiol 2005; 162:709-716.

36. Brody JG, Moysich KB, Humblet O, Attfield KR, Beehler GP, Rudel RA. Environmental pollutants and breast cancer: epidemiologic studies. Cancer 2007; 109(Suppl.12):2667-2711.

37. Cohn BA, Wolff MS, Cirillo PM, Sholtz RI. DDT and breast cancer in young women: new data on the significance of age at exposure. Environ Health Perspect 2007; 115:1406-1414.

38. Turusov V, Rakitsky V, Tomatis L. Dichlorodiphenyltrichloroethane (DDT): ubiquity, persistence, and risks. Environ Health Perspect 2002; 110:125-128.

39. Harrad S. Persistent organic pollutants: environmental behaviour and pathways of human exposure. Dordrecht, the Netherlands: Kluwer Academic Publishers; 2001.

40. Varca LM, Magallona ED. Dissipation and degradation of DDT and DDE in Philippine soil under field conditions. J Environ Sci Health 1994; 29:25-35.

41. Wandiga SO. Use and distribution of organochlorine pesticides: the future in Africa. Pure Appl Chem 2001; 73:1147-1155.

42. Ritter L, Solomon KR, Forget J, Stemeroff M, O'Leary C. Persistent organic pollutants. Geneva: International Programme on Chemical Safety; 1995.

43. Kelly BC, Gobas FAPC, McLachlan MS. Intestinal absorption and biomagnification of organic contaminants in fish, wildlife, and humans. Environ Toxicol Chem 2004; 23:2324-2336.

44. Fisk AT, de Wit CA, Wayland M, Kuzyk ZZ, Burgess $\mathrm{N}$, Letcher R, Braune B, Norstrom R, Blum SP, Sandau C, Lie E, Larsen HJ, Skaare JU, Muir DCG. An assessment of the toxicological significance of anthropogenic contaminants in Canadian arctic wildlife. Sci Total Environ 2005; 351-352:57-93.

45. Galindo RJG, Medina JA, Villagrana LC. Physiological and biochemical changes in shrimp larvae (Penaeus vannamei) intoxicated with organochlorine pesticides. Mar Pollut Bull 1996; 32:872-875.

46. Metcalf RL. A century of DDT. J Agric Food Chem 1973; 21:511-519.

47. Ratcliffe DA. Decrease in eggshell weight in certain birds of prey. Nature 1967; 215:208-210.

48. Bouwman H, Coetzee A, Schutte CHJ. Environmental and health implications of DDT-contaminated fish from the Pongolo Flood Plain. Afr J Zool 1990; 104:275-286. 
49. Dua VK, Pant CS, Sharma VP. Determination of levels of $\mathrm{HCH}$ and DDT in soil, water and whole blood from bio-environmental and insecticidesprayed areas of malaria control. Indian J Malariol 1996; 33:7-15

50. Sereda BL, Meinhardt HR. Contamination of the water environment in malaria endemic areas of KwaZuluNatal, South Africa, by DDT and its metabolites. Bull Environ Contam Toxicol 2005; 75:538-545.

51. Vieira EDR, Torres JPM, Malm O. DDT environmental persistence from its use in a vector control program: a case study. Environ Res 2001; 86:174-182.

52. Hemingway J, Ranson H. Insecticide resistance in insect vectors of human disease. Annu Rev Entomol 2000; 45:371-391.

53. Busvine JR. Current problems in the control of mosquitoes. Nature 1978; 273:604-607.

54. Mouchet J. Mini review: agriculture and vector resistance. Insect Sci Appl 1988; 9:297-302.

55. Diabate A, Baldet T, Chandre F, Akoobeto M, Guiguemde TR, Darriet F, Brengues C, Guillet P, Hemingway J, Small GJ, Hougard JM. The role of agricultural use of insecti-cides in resistance to pyrethroids in Anopheles gambiae s.l. in Burkina Faso. Am J Trop Med Hyg 2002; 67:617-622.

56. Martinez-Torres D, Chandre F, Williamson MS, Darriet F, Bergé JB, Devonshire AL, Guillet P, Pasteur N, Pauron D. Molecular charac-terization of pyrethroid knockdown resistance $(k d r)$ in the major malaria vector Anopheles gambiae s.s. Insect Mol Biol 1998; 7:179-184.

57. World Health Organization (WHO). Malaria vector control and personal protection: report of a WHO study group. WHO Technical Report Series n. 936. Geneva: World Health Organization; 2006. [accessed 22 September 2009]. Available: www.who.int/ malaria/docs/WHO-TRS-936s.pdf

58. Coleman M, Sharp B, Seocharan I, Hemingway J. Developing an evidence-based decision support system for rational insecticide choice in the control of African malaria vectors. J Med Entomol 2007; 43:663-668

59. Dash AP, Valecha N, Anvikar AR, Kumar A. Malaria in India: challenges and opportunities. J Biosci 2009; 33:583-592.

60. Sharma VP. DDT: the fallen angel. Curr Sci (Bangalore) 2003; 85:1532-1537.

61. Cui F, Raymond M, Qiao CL. Insecticide resistance in vector mosquitoes in China. Pest Manag Sci 2006; 62:1013-1022.

62. Dusfour I, Harbach RE, Manguin S. Bionomics and sys-tematics of the oriental Anopheles sundaicus complex in relation to malaria transmission and vector control. Am J Trop Med Hyg 2004; 71:518-524.

63. Grieco JP, Achee NL, Chareonviriyaphap T, Suwonkerd W, Chauhan K, Sardelis MR, Roberts DR. A new classification system for the actions of IRS chemicals traditionally used for malaria control. PLoS ONE 2007; 2(8):e716; doi:10.1371/journal.pone. 0000716 [online 8 August 2007].

64. Roberts DR, Andre RG. Insecticide resistance issues in vector-borne disease control. Am J Trop Med Hyg 1994; 50(Suppl.6):21-34.

65. Guillet P, personal communication.
66. Nauen R. Insecticide resistance in disease vectors of public health importance. Pest Manag Sci 2007; 63:628-633.

67. Hemingway J, Penilla RP, Rodriquez AD, James BM, Edge W, Rogers H, Rodríguez MH. Resistance management strategies in malaria vector mosquito control: a large-scale field trial in southern Mexico. Pestic Sci 1997; 51:375-382.

68. Penilla RP, Rodríguez AD, Hemingway J, Torres JL, Solis F, Rodríguez MH. Changes in glutathione $S$ transferase activity in DDT resistant natural Mexican populations of Anopheles albimanus under different insecticide resistance management strategies. Pestic Biochem Physiol 2006; 86:63-71.

69. Joint Monitoring Mission (JMM). National Vector Borne Disease Control Programme: joint monitoring mission report, February 2007. New Delhi: World Health Organization; 2007.

70. MacDonald G. The epidemiology and control of malaria. London: Oxford University Press; 1957.

71. N'Guessan R, Boko P, Odjo A, Akogbeto M, Yates A, Rowland M. Chlorfenapyr: a pyrrole insecticide for the control of pyrethroid or DDT resistant Anopheles gambiae (Diptera: Culicidae) mosquitoes. Acta Trop 2007; 102:69-78.

72. N'Guessan R, Corbel V, Bonnet J, Yates A, Akogbeto $M$, Rowland M. Evaluation of indoxacarb, an oxadiazine insecticide for the control of pyrethroidresistant Anopheles gambiae (Diptera: Culicidae). J Med Entomol 2007; 44:270-276.

73. Hemingway J, Beaty BJ, Rowland M, Scott TW, Sharp BL. The innovative vector control consortium: improved control of mosquito-borne diseases. Trends Parasitol 2006; 22:308-312.

74. Hawley WA, Phillips-Howard PA, ter Kuile FO, Terlouw DJ, Vulule JM, Ombok M, Nahlen BL, Gimnig JE, Kariuki SK, Kolczak MS, Hightower AW. Community-wide effects of permethrin-treated bed nets on child mortality and malaria morbidity in western Kenya. Am J Trop Med Hyg 2003; 68:121-127.

75. Lengeler C. Insecticide-treated bednets and curtains for preventing malaria; 2004. Cochrane Database Syst Rev 2:CD000363; doi:10.1002/14651858.CD000363. pub2 [online 19 April 2004].

76. Armstrong Schellenberg JRM, Abdulla S, Nathan R, Mukasa O, Marchant TJ, Kikumbih N. Effect of large-scale social marketing of insecticide-treated nets on child survival in rural Tanzania. Lancet 2001; 340:1241-1247

77. Fegan GW, Noor AM, Akhwale WS, Cousens S, Snow RW. Effect of expanded insecticide-treated bednet coverage on child survival in rural Kenya: a longitudinal study. Lancet 2007; 370:1035-1039.

78. Smith TA, Leuenberger R, Lengeler C. Child mortality and malaria transmission intensity in Africa. Trends Parasitol 2001; 17:145-149.

79. Goodman C, Coleman P, Mills A. Economic analysis of malaria control in Sub-Saharan Africa. Geneva: Global Forum for Health Research; 2000. [accessed 23 September 2009]. Available: http://www.doh. gov.za/issues/malaria/red_reference/cross_cutting/ Economics/eco5.pdf 
80. Yukich JO, Lengeler C, Tediosi F, Brown N, Mulligan JA, Chavasse D, Stevens W, Justino J, Conteh L, Maharaj R. Costs and consequences of large-scale vector control for malaria. Malar J 2008; 7:258; doi:10.1186/1475-2875-7-258 [online 17 December 2008].

81. Curtis CF, Mnzava AEP. Comparison of house spraying and insecticide-treated nets for malaria control. Bull WHO 2000; 78:1389-1400.

82. Rowland M, Freeman T, Downey G, Hadi A, Saeed M. DEET mosquito repellent sold through social marketing provides personal protection against malaria in an area of all-night mosquito biting and partial coverage of insecticide-treated nets: a casecontrol study of effectiveness. Trop Med Int Health 2004; 9:343-350.

83. Zwiebel LJ, Takken W. Olfactory regulation of mosquito-host interactions. Insect Biochem Mol Biol 2004; 34:645-652.

84. Keiser J, Singer BH, Utzinger J. Reducing the burden of malaria in different eco-epidemiological settings with environmental management: a systematic review. Lancet Infect Dis 2005; 5:695-708.

85. Walker K, Lynch M. Contributions of Anopheles larval control to malaria suppression in tropical Africa: review of achievements and potential. Med Vet Entomol 2007; 21:2-21.

86. Keiser J, Utzinger J, Singer BH. The potential of intermittent irrigation for increasing rice yields, lowering water consumption, reducing methane emissions, and controlling malaria in African rice fields. J Am Mosq Control Assoc 2002; 18:329-340.

87. Gunawardena DM, Wickremasinghe AR, Muthuwatta L, Weerasingha S, Rajakaruna J, Senanayaka T, Kotta PK, Attanayake N, Carter R, Mendis KN. Malaria risk factors in an endemic region of Sri Lanka, and the impact and cost implications of risk factor-based interventions. Am J Trop Med Hyg 1998; 58:533-542.

88. Lindsay SW, Emerson PM, Charlwood JD. Reducing malaria by mosquito-proofing houses. Trends Parasitol 2002; 18:510-514.

89. Lacey LA. Bacillus thuringiensis serovariety israelensis and Bacillus sphaericus for mosquito control. J Am Mosq Control Assoc 2007; 23(Suppl.2):133-163.

90. Fillinger U, Kannady K, William G, Vanek MJ, Dongus S, Nyika D, Geissbuhler Y, Chaki PP, Govella NJ, Mathenge EM, Singer BH, Mshinda H, Lindsay SW, Tanner M, Mtasiwa D, Castro MC, Killeen GF. A tool box for operational mosquito larval control: preliminary results and early lessons from the Urban Malaria Control Programme in Dar es Salaam, Tanzania. Malar J 2008; 7:20; doi:10.1186/1475-28757-20 [online 25 January 2008].

91. Scholte EJ, Ng'habi K, Kihonda J, Takken W, Paaijmans K, Abdulla S, Killen GF, Knols BGJ. An entomopathogenic fungus for control of adult African malaria mosquitoes. Science 2005; 308:1641-1642.

92. Okumu FO, Knols BGJ, Fillinger U. Larvicidal effects of a neem (Azadirachta indica) oil formulation on the malaria vector Anopheles gambiae. Malar J 2007; 6:63; doi:10.1186/1475-2875-6-63 [online 22 May 2007].
93. Seyoum A, Killeen GF, Kabiru EW, Knols BGJ, Hassanali A. Field efficacy of thermally expelled or live potted repellent plants against African malaria vectors in western Kenya. Trop Med Int Health 2003; 8:1005-1011.

94. Yapabandara AMGM, Curtis CF. Laboratory and field comparisons of pyriproxyfen, polystyrene beads and other larvicidal methods against malaria vectors in Sri Lanka. Acta Trop 2002; 81:211-223

95. Catteruccia F. Malaria vector control in the third millennium: progress and perspectives of molecular approaches. Pest Manag Sci 2007; 63:634-640.

96. Utzinger J, Tozan Y, Singer BH. Efficacy and costeffectiveness of environmental management for malaria control. Trop Med Int Health 2001; 6:677687.

97. Snow RW, Guerra CA, Mutheu JJ, Hay SI. International funding for malaria control in relation to populations at risk of stable Plasmodium falciparum transmission. PLoS Med 2008; 5:e142; doi:10.1371/ journal.pmed.0050142 [online 22 July 2008].

98. Najera JA, Zaim M. Malaria vector control: insecticides for indoor residual spraying. WHO/CDS/ WHOPES/2001.3. Geneva: World Health Organization; 2001.

99. Bhattarai A, Ali AS, Kachur SP, Mårtensson A, Abbas AK, Khatib R, Al-Mafazy AW, Ramsan M, Rotllant G, Gerstenmaier JF, Molteni F, Abdulla S, Montgomery SM, Kaneko A, Björkman A. Impact of artemisinin-based combi-nation therapy and insecticide-treated nets on malaria burden in Zanzibar. PLoS Med 2007; 4:e309; doi:10.1371/journal. pmed.0040309 [online 6 November 2007].

100. Nyarango PM, Gebremeskel T, Mebrahtu G, Mufunda J, Abdulmumini U, Ogbamariam A, Kosia A, Gebremichael A, Gunawardena D, Ghebrat Y, Okbaldet Y. A steep decline of malaria morbidity and mortality trends in Eritrea between 2000 and 2004: the effect of combination of control methods. Malar J 2006; 5:33; doi:10.1186/1475-2875-533 [online 24 April 2006].

101. Otten M, Aregawi M, Were W, Karema C, Medin A, Jima D, Kebede W, Gausi K, Komatsu R, Korenromp E, Low-Beer D, Grabowsky M. Initial evidence of reduction of malaria cases and deaths in Rwanda and Ethiopia due to rapid scale-up of malaria prevention and treatment. Malar J 2009; 8:14; doi:10.1186/1475-2875-8-14 [online 14 January 2009].

102. Qunhua L, Xin K, Changzhi C, Shengzheng F, Yan L, Rongzhi H, Zhihua Z, Gibson G, Wenmin K. New irrigation methods sustain malaria control in Sichuan Province, China. Acta Trop 2004; 89(2):241247.

103. Chanon KE, Mendez-Galvan JF, Galindo-Jaramilloc JM, Olguin-Bernalb H, Borja-Aburto VH. Cooperative actions to achieve malaria control without the use of DDT. Int J Hyg Environ Health 2003; 206:387-394

104. Sharma VP. Community-based malaria control in India. Parasitol Today 1987; 3:222-226.

105. Konradsen F, Matsuno Y, Amerasinghe FP, Amerasinghe PH, van der Hoek W. Anopheles culicifacies breeding in Sri Lanka and for control through water management. Acta Trop 1998; 71:131-138. 
106. van den Berg H, von Hildebrand A, Ragunathan V, Das PK. Reducing vector-borne disease by empowering farmers in integrated vector management. Bull WHO 2007; 85:561-566.

107. Hargreaves K, Koekemoer LL, Brooke B, Hunt RH, Mthembu J, Coetzee M. Anopheles funestus resistant to pyrethroid insecticides in South Africa. Med Vet Entomol 2000; 14:181-189.

108. Greenwood BM, Fidock DA, Kyle DE, Kappe SHI, Alonso PL, Collins FH, Duffy PE. Malaria: progress, perils, and pros-pects for eradication. J Clin Invest 2008; 118:1266-1276.

109. Chandre F, Darriet F, Duchon S, Finot L, Manguin S, Carnevale P, Guillet P. Modifications of pyrethroid effects associated with $k d r$ mutation in Anopheles gambiae. Med Vet Entomol 2000; 14:81-88.

110. Henry MC, Assi SB, Rogier C, Dossou-Yovo J, Chandre F, Guillet P, Carnevale P. Protective efficacy of lambda-cyhalothrin treated nets in Anopheles gambiae pyrethroid resistance areas of Cote d'Ivoire. Am J Trop Med Hyg 2005; 73:859-864.

111. N'Guessan R, Corbel V, Akogbéto M, Rowland M. Reduced efficacy of insecticide-treated nets and indoor residual spraying for malaria control in pyrethroid resistance area, Benin. Emerg Infect Dis 2007; 13:199-206.

112. Karunaratne SHPP, Hemingway J. Malathion resistance and prevalence of the malathion carboxylesterase mecha-nism in populations of mosquito vectors of disease in Sri Lanka. Bull WHO 2001; 79:1060-1064.

113. Stump AD, Atieli FK, Vulule JM, Besansky NJ. Dynamics of the pyrethroid knockdown resistance allele in Western Kenyan populations of Anopheles gambiae in response to insecticide-treated bed net trials. Am J Trop Med Hyg 2004; 70:591-596.

114. Molineaux L, Gramiccia G. The Garki project: research on the epidemiology and control of malaria in the Sudan Savanna of West Africa. Geneva: World Health Organization; 1980.

115. Pates H, Curtis C. Mosquito behavior and vector control. Annu Rev Entomol 2005; 50:53-70.

116. Phillips RS. Current status of malaria and potential for control. Clin Microbiol Rev 2001; 14:208-226.

117. Takken W. Do insecticide-treated bednets have an effect on malaria vectors? Trop Med Int Health 2002; 7:1022-1030

118. Coleman M, Hemingway J. Insecticide resistance monitoring and evaluation in disease transmitting mosquitoes. J Pestic Sci 2007; 32:69-76.

119. Barat LM. Four malaria success stories: how malaria burden was successfully reduced in Brazil, Eritrea, India, and Vietnam. Am J Trop Med Hyg 2006; 74:12-16.

120. World Bank. Rolling back malaria: the World Bank Global Strategy and Booster Program. Washington, DC: World Bank; 2005.

121. Shiff C. Integrated approach to malaria control. Clin Microbiol Rev 2002; 15:278-293.

122. Kolaczinski K, Kolaczinski J, Kilian A, Meek S. Extension of indoor residual spraying for malaria control into high transmission settings in Africa. Trans R Soc Trop Med Hyg 2007; 101:852-853.
123. Webster J, Hill J, Lines J, Hanson K. Delivery systems for insecticide treated and untreated mosquito nets in Africa: categorization and outcomes achieved. Health Policy Plan 2007; 22:277-293.

124. Pretty JN. Participatory learning for sustainable agriculture. World Dev 1995; 23:1247-1263.

125. van den Berg H, Knols BGJ. The Farmer Field School: a method for enhancing the role of rural communities in malaria control? Malar J 2006; 5:3; doi:10.1186/1475-2875-5-3 [online 19 January 2006].

126. McKenzie FE, Baird JK, Beier JC, Lal AA, Bossert WH. A biological basis for integrated malaria control. Am J Trop Med Hyg 2002; 67:571-577.

127. Utzinger J, Tanner M, Kammen DM, Killeen GF, Singer BH. Integrated programme is key to malaria control [letter]. Nature 2002; 419:431.

128. International Programme on Chemical Safety. World Health Assembly Resolution 50.13; 1997. [accessed 22 September 2009]. Available: http://www.who.int/ ipcs/publications/wha/whares_53_13/en/index.html

129. Intergovernmental Forum on Chemical Safety. Forum VI. Sixth Session of the Intergovernmental Forum on Chemical Safety, Final Report; 2008. [accessed 23 September 2009]. Available: http:// www.who.int/ifcs/documents/forums/forum6/f6_ finalreport_en.pdf

130. Dua VK, Sharma SK, Srivastava A, Sharma VP. Bioenvironmental control of industrial malaria at Bharat Heavy Electricals Ltd., Hardwar, Indi: results of a nine-year study (1987-95). J Am Mosq Control Assoc 1997; 13:278-285.

131. Sharma RC, Gautam AS, Bhatt RM, Gupta DK, Sharma VP. The Kheda malaria project: the case for environmental control. Health Policy Plan 1991; 6:262-270.

132. Singh N, Shukla MM, Mishra AK, Singh MP, Paliwal JC, Dash AP. Malaria control using indoor residual spray-ing and larvivorous fish: a case study in Betul, central India. Trop Med Int Health 2006; 11:1512-1520.

133. Takken W, Snellen WB, Verhave JP, Knols BGJ, Atmosoedjono S. Environmental measures for malaria control in Indonesia: an historical review on species sanita-tion. Wageningen Agricultural Research Papers 90.7. Wageningen, the Netherlands: Wageningen University; 1990.

134. Killeen GF, McKenzie FE, Foy BD, Schieffelin C, Billingsley PF, Beier JC. The potential impact of integrated malaria transmission control on entomologic inoculation rate in highly endemic areas. Am J Trop Med Hyg 2000; 62:545-551.

135. Killeen GF, Seyoum A, Knols BG. Rationalizing historical successes of malaria control in Africa in terms of mos-quito resource availability management. Am J Trop Med Hyg 2004; 71(Suppl.2):87-93.

136. World Health Organization (WHO). Statement on integrated vector management. WHO/HTM/NTD/ VEM/2008.2. Geneva:World Health Organization; 2008.

137. Townson H, Nathan MB, Zaim M, Guillet P, Manga $\mathrm{L}$, Bos $\mathrm{R}$, Kindhauser M. Exploiting the potential of vector control for disease prevention. Bull WHO 2005; 83:942-947. 
138. World Health Organization (WHO). Global strategic framework for integrated vector management. WHO document WHO/CDS/CPE/PVC/2004.10. Geneva: World Health Organization; 2004.

139. van den Berg H, Takken W. A framework for decision-making in integrated vector management to prevent disease. Trop Med Int Health 2007; 12:12301238.

140. Roll Back Malaria Partnership. The Global Malaria Action Plan for a Malaria-Free World; 2008. [accessed 22 September 2009]. Available: http:// rbm.who.int/gmap/

141. Feachem R, Sabot O. A new global malaria eradication strategy. Lancet 2008; 371:1633-1635.

142. Beier JC, Keating J, Githure JI, MacDonald MB, Impoinvil DE, Novak RJ. Integrated vector management for malaria control. Malar J 2009; 7(Suppl.1):S4; doi:10.1186/1475-2875-7-S1-S4 [11 December 2008].

Received 11 March 2009 Accepted 29 May 2009 